\title{
Anticancer Activity of Tabernaemontana coronaria against Carcinogen Induced Clear Cell Renal Cell Carcinoma
}

\author{
K. Poornima and V. K. Gopalakrishnan \\ Department of Biochemistry, Karpagam University, Coimbatore, Tamil Nadu 641 021, India \\ Correspondence should be addressed to K. Poornima; poorniovya@gmail.com
}

Received 5 October 2013; Accepted 6 November 2013; Published 9 February 2014

Academic Editors: J. Iovanna and Y. Liu

Copyright ( 2014 K. Poornima and V. K. Gopalakrishnan. This is an open access article distributed under the Creative Commons Attribution License, which permits unrestricted use, distribution, and reproduction in any medium, provided the original work is properly cited.

\begin{abstract}
Medicinal plants have been used for treatment of various ailments since time immemorial. Tabernaemontana coronaria is a flowering plant belonging to Apocynaceae family. Considering the very good antioxidant properties of Tabernaemontana coronaria, the anticancer property of the ethanolic extract was evaluated against DEN and Fe-NTA induced clear cell renal cell carcinoma. A group of male rats were induced with single intraperitoneal injection of DEN $(200 \mathrm{mg} / \mathrm{kg} \mathrm{bw})$ and followed by Fe-NTA $(9 \mathrm{mg} \mathrm{Fe} / \mathrm{kg} \mathrm{bw})$ twice a week for 24 weeks. Another set of two groups were induced with carcinogens and treated with plant extracts (200 and $400 \mathrm{mg} / \mathrm{kg} \mathrm{bw}$ ), respectively. Further two sets of rats were treated with only the plant extracts. The therapeutic efficacy of the ethanolic extract of Tabernaemontana coronaria was observed in terms of normalization of altered renal oxidative stress parameters like LPO and enzymic and nonenzymic antioxidants in kidney of rats. These results suggested that the plant extract could act against DEN and Fe-NTA induced clear cell renal cell carcinoma in male rats by a mechanism related to its antioxidant properties which was confirmed by histopathological studies.
\end{abstract}

\section{Introduction}

In recent years, there have been considerable efforts to search for naturally occurring substances that can inhibit, reverse, or retard the multistage carcinogenesis. Tabernaemontana coronaria (synonym: Tabernaemontana divaricata) is a flowering plant belonging to the family Apocynaceae. It is one of the diverse plant genera commonly called "milkwood." The root has a bitter bad taste. It is aphrodisiac, tonic especially to the brain, liver, and spleen [1]. The milky juice is very useful in many eye infections, especially red eye. It kills intestinal worms, and its root, when chewed, relieves tooth ache [2].

About 66 alkaloids were extracted from T. coronaria by several methods. In addition to this certain nonalkaloidal constituents such as terpenoids, steroids, enzymes, and hydrocarbons have also been isolated from $T$. coronaria. Free radical scavenging enzymes, such as superoxide dismutase, catalase, ascorbate peroxidase, glutathione reductase, and phenolic peroxidase were isolated from T. coronaria plants in India $[3,4]$. Their discoveries indicated that $T$. coronaria was a very good scavenging system to combat the effects of air pollution. Nonalkaloidal compounds isolated from root bark of $T$. coronaria exhibit pharmacological properties such as anti-inflammatory and antioxidant activity in vitro [5]. The plant has antitumour activity against IgA-N [6], antioxidant activity $[1,3]$, and analgesic effect [7].

Iron is an essential nutritional element for all life forms. But its overload may also lead to various diseases [8]. The iron complex of the chelating agent nitrilotriacetic acid is nephrotoxic [9].

Ferric nitrilotriacetate (Fe-NTA) is absorbed into portal vein through mesothelium and passes into circulation via the liver [10]. The low molecular weight Fe-NTA is easily filtered through the glomeruli into the lumen of the renal proximal tubules where $\mathrm{Fe}^{3+}$-NTA is reduced to $\mathrm{Fe}^{2+}$-NTA by the glutathione degradation products cysteine or cysteinylglycine [11]. In the brush border surface of the renal proximal convoluted tubules, $\gamma$-glutamyl transpeptidase hydrolyses glutathione to cysteinylglycine that is rapidly degraded to cysteine and glycine by dipeptidase [9]. Cysteinylglycine and 
cysteine are the proposed thiol reductants that reduce $\mathrm{Fe}^{3+}$ NTA to $\mathrm{Fe}^{2+}$-NTA. The autooxidation of $\mathrm{Fe}^{2+}$-NTA generates superoxide radicals $\left(\mathrm{O}_{2}{ }^{-}\right)$which subsequently potentiate the iron catalysed Haber-Weiss reaction to produce hydroxyl radical $\left(\mathrm{OH}^{*}\right)$, leading to induction of lipid peroxidation and oxidative DNA damage $[7,8]$. Oxidatively modified molecules were found to be increased in kidney including DNA point mutations, DNA cross-linking, and DNA strand breaks and thus alter normal cells [12].

It has also been demonstrated that $\mathrm{N}$-diethylnitrosamine (DEN) pretreatment increases tumor incidence and reduces the time of treatment necessary to induce cancer as compared with Fe NTA-alone-treated animals $[13,14]$.

Taking in view the previous findings, the efficacy of the whole plant of Tabernaemontana coronaria against renal carcinogenesis, oxidative stress in rat kidney has been carried out in this study.

\section{Materials and Methods}

2.1. Plant Material. The whole plant of Tabernaemontana coronaria (Jacq.) Willd. was collected in and around Coimbatore district of Tamil Nadu, India, and authenticated by Dr. P. Satyanarayana, Scientist D, Botanical Survey of India, Southern Regional Centre, Tamil Nadu Agricultural University Campus, Coimbatore, Tamil Nadu, India. The Voucher number is BSI/SRC/5/23/2011-12/Tech. 1538. The whole plant was cut into pieces, cleaned, and air dried at $25^{\circ} \mathrm{C}$ for 10 days in the absence of sunlight and powdered well into a coarse powder using a mixer. Then they were weighed and kept in an airtight container and stored in refrigerator for future use.

2.1.1. Preparation of Extract. $50 \mathrm{~g}$ of the powdered whole plant material of Tabernaemontana coronaria was extracted by continuous extraction using soxhlet apparatus with the solvent ethanol for $72 \mathrm{hrs}$. The resultant extract was concentrated to dryness under reduced pressure below $40^{\circ} \mathrm{C}$ in rotary evaporator and stored at $4^{\circ} \mathrm{C}$ in a tightly capped brown bottle and kept in refrigerator for the study. According to OECD guidelines the doses were determined and administered.

2.1.2. Preparation of Fe-NTA Solution. Fe NTA solution was prepared fresh immediately before its use by the method of Awai et al. [15] as modified by Athar and Iqbal [13]. To prepare Fe NTA, ferric nitrate $(0.16 \mathrm{mmol} / \mathrm{kg}$ body weight $)$ solution was mixed with fourfold molar excess of disodium salt of NTA $(0.64 \mathrm{nmol})$ and the $\mathrm{pH}$ was adjusted to 7.4 with sodium bicarbonate solution. The concentration of the $\mathrm{Fe}$ NTA solution prepared was $10 \mathrm{~mL} / \mathrm{kg}$ body weight and the dose was $9 \mathrm{mg} \mathrm{Fe} / \mathrm{kg}$ body weight.

2.1.3. Animals. Adult male Albino rats weighing about $120-$ $140 \mathrm{~g}$ were obtained from the animal house of Karpagam Arts and Science College, Coimbatore, India. The animals were maintained under standard conditions and were housed four per cage in polypropylene cages with a wire mesh top and a hygienic bed of husk in a specific pathogen-free animal room under controlled conditions of $12 \mathrm{~h}$ light and $12 \mathrm{~h}$ dark cycle, with temperature of $24 \pm 2^{\circ} \mathrm{C}$, relative humidity of $50 \pm 10 \%$, and fed with rodent diet and water ad libitum. The study was approved by the Committee for the Purpose of Control and Supervision of Experiments on Animals (CPCSEA), Government of India.

2.1.4. Induction of Carcinogen. The carcinogenesis was initiated by a single intraperitoneal injection of DEN (diethyl nitrosamine) at a dose level of $200 \mathrm{mg} / \mathrm{kg}$ body weight. After ten days the carcinogenesis is promoted by Fe-NTA (ferric nitrilo tetra acetic acid) at a dose level of $9 \mathrm{mg} \mathrm{Fe} / \mathrm{kg}$ body weight (ip) twice a week for 24 weeks.

2.1.5. Experimental Protocol. Thirty-six albino rats were randomly allocated to six groups of six rats each.

(1) Group I received only normal food and water.

(2) Group II received a single intraperitoneal injection of DEN at a dose level of $200 \mathrm{mg} / \mathrm{kg}$ body weight on the first day and after ten days the carcinogenesis was promoted by Fe NTA at a dose level of $9 \mathrm{mg} \mathrm{Fe} / \mathrm{kg}$ body weight (ip) twice a week for twenty four weeks.

(3) Groups III and IV were induced with carcinogen and simultaneously treated with the plant extract (200 and $400 \mathrm{mg} / \mathrm{kg}$ body weight), respectively, daily for twenty-four weeks.

(4) Groups V and VI were treated with only the plant extract (200 and $400 \mathrm{mg} / \mathrm{kg}$ body weight), respectively, daily for twenty-four weeks.

All rats were sacrificed $12 \mathrm{~h}$ after the experimental period. Blood was collected and the separated serum was used for the estimation of urea [16], BUN [17], and creatinine [18].

2.1.6. Preparation of Tissue Homogenate. Kidneys were removed quickly and washed in ice cold isotonic saline. The kidneys were homogenized in $0.1 \mathrm{M}$ Tris- $\mathrm{HCl}$ buffer of $\mathrm{pH} 7.4$ at $4^{\circ} \mathrm{C}$ in a potter homogenizer, at $600 \mathrm{rpm}$ for 3 minutes. The filtrate was used for estimations.

2.1.7. Estimation of Tumour Marker Enzymes. The tumour marker enzymes such as gamma glutamyl transpeptidase [19], xanthine oxidase [20], and lactate dehydrogenase [21] were assayed in kidney homogenate.

2.1.8. Estimation of Superoxide Dismutase. Superoxide dismutase activity was measured by the method of Das et al. [22]. The method involves generation of superoxide radical of riboflavin and its detection by nitrite formation from hydroxylamine hydrochloride. The absorbance of the end product red azo compound was measured at $543 \mathrm{~nm}$.

2.1.9. Estimation of Catalase. Catalase activity was measured by the method of Sinha [23]. This method is based on the reduction of dichromate in acetic acid to chromic acetate when heated in the presence of hydrogen peroxide. The chromic acetate was measured colorimetrically at $610 \mathrm{~nm}$. 


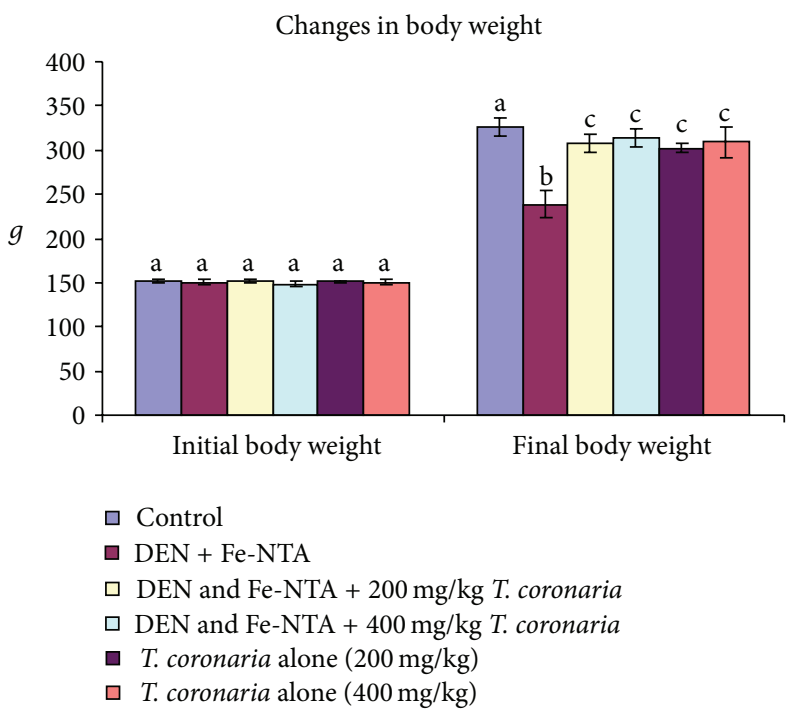

FIGURE 1: Changes in body weight of control and experimental animals. Values are expressed as mean \pm SD $(n=6)$. Values not sharing the common superscript (a-c) differ significantly (DMRT).

2.1.10. Estimation of Glutathione Peroxidase. A known amount of enzyme preparation was allowed to react with hydrogen peroxide in the presence of GSH for a specified time period. The amount of unreacted GSH was measured by Ellman's method [24].

2.1.11. Estimation of Glutathione S Transferase. Glutathione S transferase activity was assayed by the method of Habig et al. [25]. The method is based on the rate of conjugate formation between GSH and 1-chloro-2,4-dinitrobenzene (CDNB). The absorbance change was recorded at $340 \mathrm{~nm}$ and the enzyme activity calculated as nmol CDNB conjugates formed $/ \mathrm{min} / \mathrm{mg}$ protein.

2.1.12. Estimation of Reduced Glutathione. Reduced GSH in tissue homogenate was determined by measuring the rate of formation of chromophoric product in a reaction between $5,5^{\prime}$-dithiobis-2-(nitrobenzoic acid) (DTNB) and free sulphydryl groups, such as GSH, at $412 \mathrm{~nm}$ as described by Ellman [26].

2.1.13. Estimation of Vitamin C. The oxidized product of ascorbic acid was treated with 2,4 dinitrophenylhydrazine and the absorption maxima of the product was measured at $520 \mathrm{~nm}$ as described by Omaye et al. [27].

2.1.14. Estimation of Total Sulphydryl Group. The sulphydryl groups in tissues were determined using Elman's reagent. In this method DTNB reduced by SH group to form 1 mole of 2-nitro 5-mercaptobenzoic acid per mole SH [28].

2.1.15. Estimation of Lipid Peroxidation. Malondialdehyde and other TBARS were estimated by their reactivity with thiobarbituric acid in acidic condition to generate a pink coloured chromophore which was read at $535 \mathrm{~nm}$ [29].
2.2. Statistical Analysis. The results are expressed as mean \pm SD. Statistical significance was evaluated by one way analysis of variance (ANOVA) using SPSS version 16.0 and the individual comparison was obtained by the Duncan multiple range test (DMRT) [30]. A value of $P<0.05$ was considered to indicate a significant difference between groups.

\section{Results}

3.1. Changes in Body Weight in the Experimental Rats. From the Figure 1 it is found that a significant increase in body weight was noticed in all groups of rats at the end of six months when compared to the initial body weight. Treatment with DEN and Fe NTA resulted in a drastic depletion of the weight when compared to the control group. In the case of final body weight after six months compared to group I the weight gain in group II was very less. This is attributed to a heavy weight loss in the case of DEN and Fe NTA treated rats. T. coronaria treatment (200 and $400 \mathrm{mg} / \mathrm{kg}$ body weight) recovered the levels almost near to control as compared with DEN and Fe NTA treated group. The weight gain is slightly less in groups V and VI rats when compared to group I.

3.2. Changes in the Level of Urea, Creatinine, and BUN in Serum of Rats. The effect of anticancer treatment with $T$. coronaria on DEN and Fe NTA induced increment in the level of urea, creatinine, and BUN is shown in Table 1. Treatment with DEN and Fe NTA caused an increase in the levels of renal markers such as urea, creatinine, and BUN when compared to that of the control group. On treatment with $T$. coronaria at lower (200 mg/kg body weight) and higher $(400 \mathrm{mg} / \mathrm{kg}$ body weight) doses, a pronounced recovery of the above marker levels was noticed as compared with the DEN and Fe NTA treated control group. Plant extracts-alone-treated groups showed almost similar results as that of control. 
TABLE 1: Effect of Tabernaemontana coronaria on DEN and Fe-NTA induced increment in the level of urea, creatinine, and BUN in serum of rats.

\begin{tabular}{lccc}
\hline Particulars & Urea $(\mathrm{mg} / \mathrm{dL})$ & Creatinine $(\mathrm{mg} / \mathrm{dL})$ & BUN $(\mathrm{mg} / \mathrm{dL})$ \\
\hline Control & $22.38 \pm 1.17^{\mathrm{a}}$ & $0.42 \pm 0.03^{\mathrm{a}}$ & $10.43 \pm 0.54^{\mathrm{a}}$ \\
DEN + Fe-NTA & $44.05 \pm 1.48^{\mathrm{b}}$ & $1.33 \pm 0.01^{\mathrm{b}}$ & $20.53 \pm 0.69^{\mathrm{b}}$ \\
DEN and Fe-NTA + $200 \mathrm{mg} / \mathrm{kg}$ T. coronaria & $29.76 \pm 0.98^{\mathrm{c}}$ & $0.58 \pm 0.04^{\mathrm{c}}$ & $13.87 \pm 0.45^{\mathrm{c}}$ \\
DEN and Fe-NTA + $400 \mathrm{mg} / \mathrm{kg}$ T. coronaria & $23.21 \pm 1.48^{\mathrm{a}}$ & $0.45 \pm 0.03^{\mathrm{a}}$ & $10.82 \pm 0.69^{\mathrm{a}}$ \\
T. coronaria alone $(200 \mathrm{mg} / \mathrm{kg})$ & $20.01 \pm 2.35^{\mathrm{a}}$ & $0.4 \pm 0.02^{\mathrm{a}}$ & $9.32 \pm 1.09^{\mathrm{d}}$ \\
T. coronaria alone $(400 \mathrm{mg} / \mathrm{kg})$ & $20.6 \pm 3.04^{\mathrm{a}}$ & $0.4 \pm 0.01^{\mathrm{a}}$ & $9.6 \pm 1.42^{\mathrm{d}}$ \\
\hline
\end{tabular}

Values are expressed as mean $\pm \mathrm{SD}(n=6)$.

Values not sharing the common superscript (a-d) differ significantly (DMRT).

TABLE 2: Effect of T. coronaria on DEN and Fe-NTA induced enhancement of $\gamma$-glutamyl transpeptidase, xanthine oxidase, and lactate dehydrogenase in kidney.

\begin{tabular}{lccc}
\hline Particulars & $\gamma$-glutamyl transpeptidase & Xanthine oxidase & LDH \\
\hline Control & $389.97 \pm 5.53^{\mathrm{a}}$ & $0.35 \pm 0.003^{\mathrm{a}}$ & $38.77 \pm 1.17^{\mathrm{a}}$ \\
DEN + Fe-NTA & $692.68 \pm 15.84^{\mathrm{b}}$ & $0.68 \pm 0.01^{\mathrm{b}}$ & $78.70 \pm 1.38^{\mathrm{b}}$ \\
DEN and Fe-NTA $+200 \mathrm{mg} / \mathrm{kg}$ T. coronaria & $523.24 \pm 7.48^{\mathrm{c}}$ & $0.51 \pm 0.007^{\mathrm{c}}$ & $69.15 \pm 1.42^{\mathrm{c}}$ \\
DEN and Fe-NTA $+400 \mathrm{mg} / \mathrm{kg}$ T. coronaria & $446.34 \pm 5.17^{\mathrm{d}}$ & $0.4 \pm 0.009^{\mathrm{d}}$ & $45.58 \pm 1.39^{\mathrm{d}}$ \\
T. coronaria alone $(200 \mathrm{mg} / \mathrm{kg})$ & $394.82 \pm 3.26^{\mathrm{a}}$ & $0.34 \pm 0.005^{\mathrm{a}}$ & $39.63 \pm 0.77^{\mathrm{a}}$ \\
T. coronaria alone $(400 \mathrm{mg} / \mathrm{kg})$ & $383.26 \pm 2.86^{\mathrm{a}}$ & $0.32 \pm 0.004^{\mathrm{a}}$ & $37.10 \pm 0.72^{\mathrm{a}}$ \\
\hline
\end{tabular}

Values are expressed as mean $\pm \mathrm{SD}(n=6)$.

Values not sharing the common superscript (a-d) differ significantly (DMRT).

$\gamma$-glutamyl transpeptidase, xanthine oxidase-units/mg protein.

$\mathrm{LDH}$, nmoles of pyruvate liberated/min/mg protein.

From Table 2 it is found that the level of gamma glutamyl transpeptidase, xanthine oxidase, and lactate dehydrogenase were increased significantly in DEN and Fe NTA induced group II animals when compared to the control rats.

This increased level was reduced to near normal level when treated simultaneously with the plant extract. This might be due to the potent antioxidant activity of the plant extract and it is an indication of the reversal of the damage caused by DEN and Fe NTA by the ethanolic extract of Tabernaemontana coronaria. No significant change is noted in groups V and VI when compared to that of control animals. This shows the protective nature of the plant extract and the plant is nontoxic to humans.

From Table 3 it is found that a significant reduction $(P<0.05)$ in the activities of antioxidant enzymes, namely, superoxide dismutase, catalase, glutathione peroxidase, and glutathione $\mathrm{S}$ transferase, was noted in rats intoxicated with DEN and Fe NTA (group II) when compared to control (group I). Whereas in groups III and IV rats treated with $200 \mathrm{mg}$ and $400 \mathrm{mg} / \mathrm{kg}$ bw of ethanolic extract of Tabernaemontana coronaria the level of these enzymes were significantly increased when compared to group II animals.

3.3. Changes in the Level of GSH, Vitamin C, and Total Sulphydryl Group in Kidney. From Table 4 it is found that DEN and Fe NTA treatment reduces the activity of GSH, vitamin $\mathrm{C}$, and total sulphydryl group in group II animals. This decrement in the antioxidant activity is increased gradually by treating simultaneously with the plant extract $T$. coronaria (200 and $400 \mathrm{mg} / \mathrm{kg}$ body weight). Compared to group III, group IV animals showed better result in increasing the antioxidant level. The plant extract-alone-treated groups showed results similar to that of the control rats.

3.4. Lipid Peroxidation in Kidney. From Figure 2 it is found that the level of lipid peroxidation is increased $(P<$ 0.05 ) significantly in DEN and Fe NTA induced group II animals when compared to the control (group I) animals. Administration of the ethanolic extract of Tabernaemontana coronaria decreased the lipid peroxidation index $(P<0.05)$ significantly.

In the plant extract-alone-treated groups (V and VI) no significant alteration was seen and the values are also similar to that of control.

3.5. Histopathology of Kidney in Control and Experimental Rats. From Figure 3 it is found that the histopathology of group I untreated normal rats showed no pathological changes. Whereas in DEN and Fe NTA treated group II rats, the cortex shows numerous small foci of proliferation composed of cells with clear cytoplasm and a peripherally displaced round nucleus (multicentric clear cell carcinoma). The interstitium shows patchy lymphoid aggregates. In group III when the plant extract $(200 \mathrm{mg} / \mathrm{kg})$ is administered along with the carcinogen, the cortex showed a large cyst lined by flattened epithelium surrounded by normal renal tissue. Clear cell aggregates are not seen. Stroma shows patchy lymphoid aggregates. The increased concentration of plant extract $(400 \mathrm{mg} / \mathrm{kg})$ in Group IV showed better results than that of group III $(200 \mathrm{mg} / \mathrm{kg})$ where the cortex showed a large cyst 
TABLE 3: Effect of T. coronaria on DEN and Fe-NTA induced depletion of superoxide dismutase, catalase, glutathione peroxidase, and glutathione $\mathrm{S}$ transferase in kidney.

\begin{tabular}{lcccc}
\hline Particulars & Superoxide dismutase & Catalase & Glutathione peroxidase & Glutathione S transferase \\
\hline Control & $6.26 \pm 0.33^{\mathrm{a}}$ & $3.29 \pm 0.40^{\mathrm{a}}$ & $33.27 \pm 0.97^{\mathrm{a}}$ & $205.84 \pm 3.6^{\mathrm{a}}$ \\
DEN + Fe-NTA & $3.62 \pm 0.41^{\mathrm{b}}$ & $2.13 \pm 0.11^{\mathrm{b}}$ & $15.98 \pm 0.64^{\mathrm{b}}$ & $132.48 \pm 4.9^{\mathrm{b}}$ \\
DEN and Fe-NTA + $200 \mathrm{mg} / \mathrm{kg}$ T. coronaria & $4.97 \pm 0.32^{\mathrm{c}}$ & $3.08 \pm 0.07^{\mathrm{a}}$ & $24.8 \pm 0.54^{\mathrm{c}}$ & $165.60 \pm 5.2^{\mathrm{c}}$ \\
DEN and Fe-NTA + $400 \mathrm{mg} / \mathrm{kg}$ T. coronaria & $6.18 \pm 0.43^{\mathrm{a}}$ & $3.65 \pm 0.34^{\mathrm{c}}$ & $38.66 \pm 0.71^{\mathrm{d}}$ & $207.37 \pm 2.9^{\mathrm{a}}$ \\
T. coronaria alone $(200 \mathrm{mg} / \mathrm{kg})$ & $6.48 \pm 0.59^{\mathrm{a}}$ & $3.19 \pm 0.03^{\mathrm{a}}$ & $38.89 \pm 0.54^{\mathrm{d}}$ & $206.4 \pm 1.66^{\mathrm{a}}$ \\
T. coronaria alone $(400 \mathrm{mg} / \mathrm{kg})$ & $7.0 \pm 0.86^{\mathrm{a}}$ & $3.91 \pm 0.09^{\mathrm{d}}$ & $39.43 \pm 0.47^{\mathrm{d}}$ & $208.9 \pm 1.22^{\mathrm{a}}$ \\
\hline
\end{tabular}

Values are expressed as mean $\pm \mathrm{SD}(n=6)$.

Values not sharing the common superscript (a-d) differ significantly (DMRT).

SOD_unit/mg protein.

CAT $-\mu$ moles of $\mathrm{H}_{2} \mathrm{O}_{2}$ consumed $/ \mathrm{min} / \mathrm{mg}$ protein.

$\mathrm{GPx}-\mu \mathrm{g}$ of glutathione consumed/minute/mg protein.

GST: $n$ moles of CDNB conjugated $/ \mathrm{min} / \mathrm{mg}$ protein.

TABLE 4: Changes in the level of GSH, vitamin C, and total sulphydryl group in kidney.

\begin{tabular}{lccc}
\hline Particulars & GSH & Vitamin C & Total sulphydryl group \\
\hline Control & $8.28 \pm 0.24^{\mathrm{a}}$ & $1.87 \pm 0.14^{\mathrm{a}}$ & $4.71 \pm 0.07^{\mathrm{a}}$ \\
DEN + Fe-NTA & $4.01 \pm 0.21^{\mathrm{b}}$ & $0.92 \pm 0.05^{\mathrm{b}}$ & $3.22 \pm 0.23^{\mathrm{b}}$ \\
DEN and Fe-NTA + $200 \mathrm{mg} / \mathrm{kg}$ T. coronaria & $6.39 \pm 0.29^{\mathrm{c}}$ & $1.7 \pm 0.07^{\mathrm{c}}$ & $3.58 \pm 0.09^{\mathrm{c}}$ \\
DEN and Fe-NTA $+400 \mathrm{mg} / \mathrm{kg}$ T. coronaria & $7.56 \pm 0.31^{\mathrm{a}}$ & $1.76 \pm 0.03^{\mathrm{c}}$ & $4.46 \pm 0.12^{\mathrm{d}}$ \\
T. coronaria alone $(200 \mathrm{mg} / \mathrm{kg})$ & $7.98 \pm 0.25^{\mathrm{a}}$ & $1.75 \pm 0.08^{\mathrm{c}}$ & $4.45 \pm 0.09^{\mathrm{d}}$ \\
T. coronaria alone $(400 \mathrm{mg} / \mathrm{kg})$ & $8.96 \pm 0.22^{\mathrm{e}}$ & $1.93 \pm 0.04^{\mathrm{a}}$ & $4.53 \pm 0.07^{\mathrm{d}}$ \\
\hline
\end{tabular}

Values are expressed as mean $\pm \mathrm{SD}(n=6)$.

Values not sharing the common superscript (a-e) differ significantly (DMRT).

The units were expressed in $\mu \mathrm{g} / \mathrm{mg}$ protein.

lined by flattened epithelium surrounded by normal renal tissue. Clear cell aggregates are not seen. Stroma shows patchy lymphoid aggregates.

\section{Discussion}

Various plants of medicinal value are used in chemopreventive studies, owing to the increase in the incidences and severity of the cancer disease. These plants work by inhibiting the development of invasive cancer either by blocking initiation or by arresting or reversing the progression of premalignant cells [29]. Traditional medical practitioners utilized plants for the treatment of several diseases since time immemorial. Recent studies have shown that plants have several active agents or compounds due to which they show more synergistic effect than any single active compound [30].

The role of reactive oxygen species in tumor initiation, promotion, and progression has been reported in various studies [31]. The phytochemical analysis of the various extracts of T. coronaria has shown that it contains alkaloid, saponin, tannins, phenolic compounds, flavonoid, cardioglycosides, terpenoid, amino acids, protein, and carbohydrates [32]. The antioxidative effects of $T$. coronaria have been studied by various investigators $[1,3]$. Further, the free radical scavenging ability of the plant is also demonstrated by various researchers [3]. Their results demonstrated that the plant has high level of antioxidative agents such as SOD, CAT, GSH, ascorbate peroxidase, and phenolic peroxidase. The results of the experiments in the present study indicate that renal carcinogenesis initiated by single intraperitoneal injection of DEN and promoted by Fe-NTA is effectively, dose-dependently inhibited by the subsequent administration of the ethanolic extract of Tabernaemontana coronaria.

Previous studies have shown that the dietary supplementation of plant based products protects against Fe NTA induced renal tumour promotion response which was evidenced by lipid peroxidation and antioxidant enzymes and proved by histopathological studies [33-35]. Likewise Tabernaemontana coronaria may also be envisaged to mediate protection against DEN and Fe NTA induced oxidative stress and it was evidenced by the improved activities of antioxidant enzymes, namely, superoxide dismutase, catalase, glutathione peroxidase, reduced glutathione, vitamin $\mathrm{C}$, and total sulphydryl group and phase-II metabolizing enzyme glutathione $S$ transferase. Glutathione $S$ transferase is a prominent phaseII enzyme involved in detoxification, conjugation, and elimination of carcinogens in the form of glucuronides, sulfates, and glutathione conjugates. Glutathione $S$ transferase, used as a marker for evaluating anticarcinogenic potential, catalyzes electrophilic conjugation with reduced glutathione, thus counteracting a variety of carcinogens. Glutathione as the main component of endogenous nonprotein sulphydryl pool participating as scavenger of free radicals, reducing peroxides and conjugating with electrophilic compounds, thus protecting the cell with multiple defenses not only against ROS but also against their toxic products $[33,36]$. 


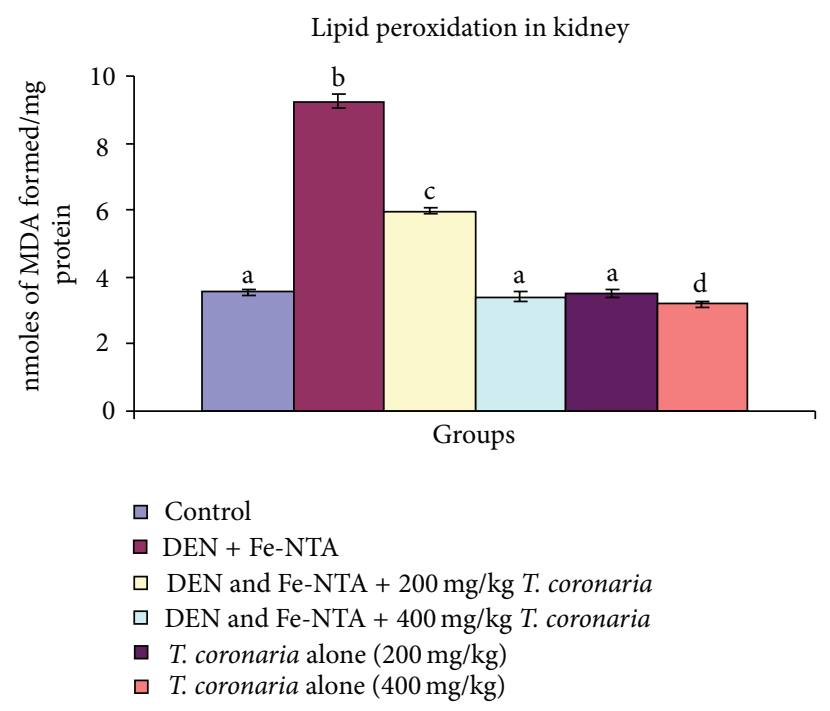

FIGURE 2: Lipid peroxidation in kidney. Values are expressed as mean \pm SD $(n=6)$. Values not sharing the common superscript (a-d) differ significantly (DMRT).

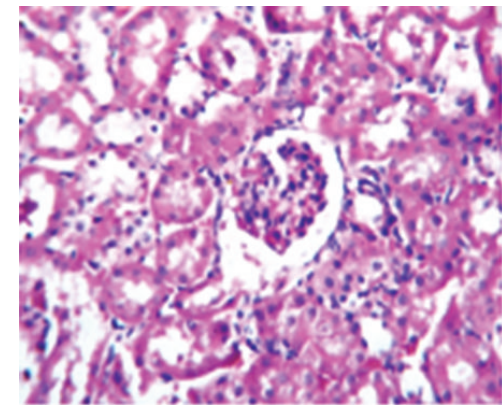

Control

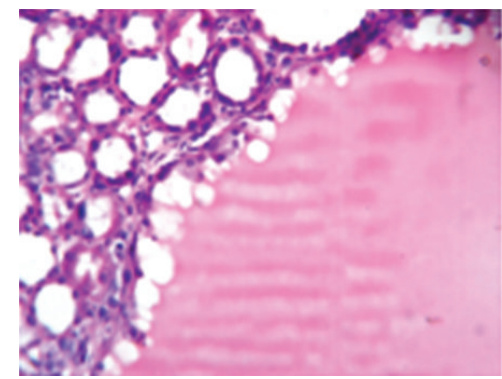

$\mathrm{Car}+\mathrm{PE}(400 \mathrm{mg} / \mathrm{kg} \mathrm{bw})$

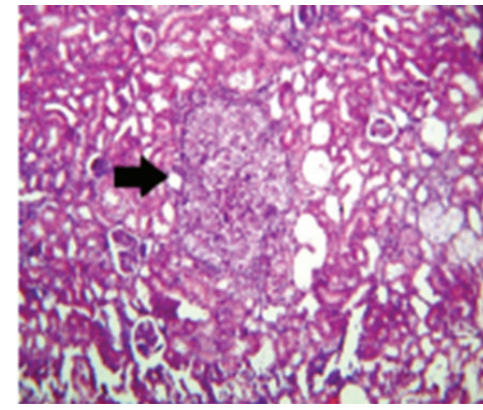

Carcinogen

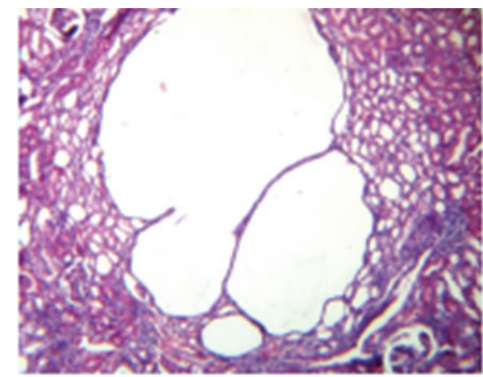

$\mathrm{PE}(200 \mathrm{mg} / \mathrm{kg} \mathrm{bw})$

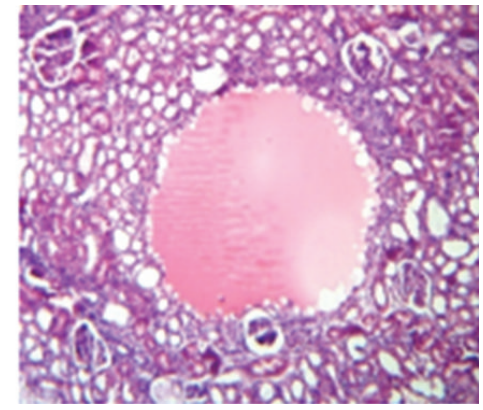

Car + PE (200 mg/kg bw)

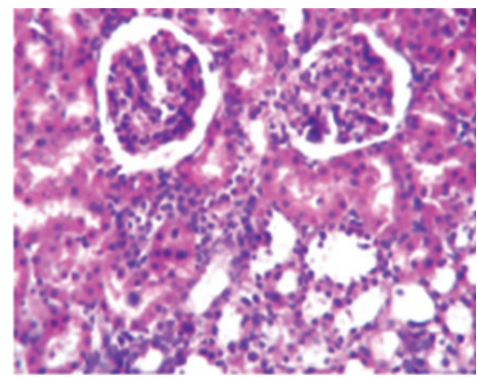

$\mathrm{PE}(400 \mathrm{mg} / \mathrm{kg} \mathrm{bw})$

FIgURE 3: Histopathology of kidney.

The enhanced values of xanthine oxidase, $\gamma$-glutamyl transpeptidase, and lactate dehydrogenase content were also recovered on treatment with Tabernaemontana coronaria. An increase in activity of $\gamma$-glutamyl transpeptidase may lead to the accumulation of glycine and cysteine, thereby reducing Fe-NTA to its ferrous complex and enhancing peroxidative damage to the membrane/tissue.

T. coronaria pretreatment caused a marked reduction in the level of blood urea nitrogen and serum creatinine of kidney damage showing that prophylaxis of the plant is effective in improving kidney function in Fe-NTA treated group.

\section{Conclusion}

To conclude, the plant has a very good antioxidant and anticancer effect against clear cell renal cell carcinoma induced by DEN and Fe-NTA in male Wistar Albino rats and it can be used for the purpose of anticancer therapy. 


\section{Conflict of Interests}

The authors declare that there is no conflict of interests regarding the publication of this paper.

\section{Acknowledgment}

The authors are thankful to their Chancellor, Chief Executive Officer, Vice Chancellor, and Registrar of Karpagam University for providing facilities and encouragement.

\section{References}

[1] M. Gupta, U. K. Mazumder, R. S. Kumar, T. Sivakumar, and P. Gomathi, "Antioxidant and protective effects of Ervatamia coronaria stape., leaves against carbon tetrachloride induced liver injury," European Bulletin of Drug Research, vol. 12, pp. 1322, 2004.

[2] P. T. Thambi, B. Kuzhivelil, M. Sabu, and C. Jolly, "Antioxidant and antiinflammatory activities of the flowers of Tabernaemontana coronaria (L) R.Br," Indian Journal of Pharmaceutical Sciences, vol. 68, no. 3, pp. 352-355, 2006.

[3] M. Mandal and S. Mukherji, "A study on the activities of a few free radicals scavenging enzymes present in five roadside plants," Journal of Environmental Biology, vol. 22, no. 4, pp. 301305, 2001.

[4] W. Pratchayasakul, A. Pongchaidecha, N. Chattipakorn, and S. Chattipakorn, "Ethnobotany and ethnopharmacology of Tabernaemontana divaricata," Indian Journal of Medical Research, vol. 127, no. 4, pp. 317-335, 2008.

[5] I. J. Flores-Sánchez, J. Ortega-López, M. Del Carmen MontesHorcasitas, and A. C. Ramos-Valdivia, "Biosynthesis of sterols and triterpenes in cell suspension cultures of Uncaria tomentosa," Plant and Cell Physiology, vol. 43, no. 12, pp. 1502-1509, 2002.

[6] A. C. Smith and J. Feehally, "New insights into the pathogenesis of IgA nephropathy: pathogenesis of IgA nephropathy," Springer Seminars in Immunopathology, vol. 24, no. 4, pp. 477-493, 2003.

[7] A. T. Henriques, A. A. Melo, P. R. H. Moreno, L. L. Ene, J. A. P. Henriques, and E. E. S. Schapoval, "Ervatamia coronaria: chemical constituents and some pharmacological activities," Journal of Ethnopharmacology, vol. 50, no. 1, pp. 19-25, 1996.

[8] J. M. De Freitas and R. Meneghini, "Iron and its sensitive balance in the cell," Mutation Research, vol. 475, no. 1-2, pp. 153-159, 2001.

[9] N. Khan and S. Sultana, "Chemomodulatory effect of Ficus racemosa extract against chemically induced renal carcinogenesis and oxidative damage response in Wistar rats," Life Sciences, vol. 77, no. 11, pp. 1194-1210, 2005.

[10] T. Y. Umemura, K. Sai, A. Takagi, R. Hasegawa, and Y. Kurokawa, "Oxidative DNA damage, lipid peroxidation and nephrotoxicity induced in the rat kidney after ferric nitrilotriacetate administration," Cancer Letters, vol. 54, no. 1-2, pp. 95-100, 1990.

[11] B. Tsao and N. P. Curthoys, "The absolute asymmetry of orientation of gamma-glutamyltranspeptidase and aminopeptidase on the external surface of the rat renal brush border membrane," Journal of Biological Chemistry, vol. 255, no. 16, pp. 7708-7711, 1980.

[12] B. Halliwell and O. I. Aruoma, Eds., DNA and Free Radicals, CRC Press, Boca Raton, Fla, USA, 1993.
[13] M. Athar and M. Iqbal, "Ferric nitrilotriacetate promotes Ndiethylnitrosamine-induced renal tumorigenesis in the rat: implications for the involvement of oxidative stress," Carcinogenesis, vol. 19, no. 6, pp. 1133-1139, 1998.

[14] T. Jahangir and S. Sultana, "Modulatory effects of Pluchea lanceolata against chemically induced oxidative damage, hyperproliferation and two-stage renal carcinogenesis in wistar rats," Molecular and Cellular Biochemistry, vol. 291, no. 1-2, pp. 175$185,2006$.

[15] M. Awai, M. Narasaki, Y. Yamanoi, and S. Seno, "Induction of diabetes in animals by parenteral administration of ferric nitrilotriacetate A model of experimental hemochromatosis," American Journal of Pathology, vol. 95, no. 3, pp. 663-673, 1979.

[16] S. Natelson, M. L. Scott, and C. Beffa, "A rapid method for the estimation of urea in biologic fluids," American Journal of Clinical Pathology, vol. 21, no. 3, pp. 275-281, 1951.

[17] M. W. Kanter, Clinical Chemistry, The Bobber Merrill Company, Indianapolis, Ind, USA, 1975.

[18] J. A. Owen, J. B. Iggo, F. J. Scangrett, and I. P. Steward, "The determination of creatinine in plasma or serum, and in urine; a critical examination," The Biochemical Journal, vol. 58, no. 3, pp. 426-437, 1954.

[19] K. Orlowski and A. Meister, "Isolation of gamma glutamyl transpeptidase from hog kidney," The Journal of Biological Chemistry, vol. 240, pp. 338-347, 1965.

[20] R. Fried and L. W. Fried, "Xanthine oxidase (xanthine dehydrogenase)," in Methods of Enzymatic Analysis, Bergmeyer, Ed., vol. 2, p. 644, Verlay Chemic, Weinhein, Germany; Academic Press, New York, NY, USA, 1966.

[21] J. King, "The dehydrogenase or oxido reductase-lactate dehydrogenase," in Practical Clinical Enzymology, D. Van, Ed., pp. 83-93, Norstand Company, Ontario, Canada, 1965.

[22] S. Das, S. Vasishat, R. Snehlata, N. Das, and L. M. Srivastava, "Correlation between total antioxidant status and lipid peroxidation in hypercholesterolemia," Current Science, vol. 78, pp. 486-487, 2000.

[23] A. K. Sinha, "Colorimetric assay of catalase," Analytical Biochemistry, vol. 47, no. 2, pp. 389-394, 1972.

[24] J. T. Rotruck, A. L. Pope, H. E. Ganther, A. B. Swanson, D. G. Hafeman, and W. G. Hoekstra, "Selenium: biochemical role as a component of glatathione peroxidase," Science, vol. 179, no. 4073, pp. 588-590, 1973.

[25] W. H. Habig, M. J. Pabst, and W. B. Jakoby, "Glutathione S transferases. The first enzymatic step in mercapturic acid formation," Journal of Biological Chemistry, vol. 249, no. 22, pp. 7130-7139, 1974.

[26] G. L. Ellman, "Determination of sulfhydryl group," Archives of Biochemistry and Biophysics, vol. 82, pp. 70-74, 1959.

[27] S. T. Omaye, J. David Turnbull, and H. E. Sauberlich, "Selected methods for the determination of ascorbic acid in animal cells, tissues, and fluids," Methods in Enzymology C, vol. 62, pp. 3-11, 1979.

[28] J. Sedlack and R. H. Lindsay, "Estimation of total protein bound and non-protein bound sulphydryl groups in the tissue with Ellman'sreagent," Analytical Biochemistry, vol. 25, pp. 192-205, 1968.

[29] L. W. Wattenberg, "An overview of chemoprevention: current status and future prospects," Proceedings of the Society for Experimental Biology and Medicine, vol. 216, no. 2, pp. 133-141, 1997. 
[30] A. Chesson and A. Collins, "Assessment of the role of diet in cancer prevention," Cancer Letters, vol. 114, no. 1-2, pp. 237-245, 1997.

[31] P. A. Cerutti, "Prooxidant states and tumor promotion," Science, vol. 227, no. 4685, pp. 375-381, 1985.

[32] S. Surya, K. Poornima, G. Ravikumar et al., "In Vitro antioxidant activity and phytochemical screening of ethanolic extract of Tabernaemontana coronaria (L.)," Pharmacologyonline, vol. 2, pp. 212-218, 2011.

[33] T. Jahangir and S. Sultana, "Modulatory effects of Pluchea Lanceolata against chemically induced oxidative damage, hyperproliferation and two-stage renal carcinogenesis in wistar rats," Molecular and Cellular Biochemistry, vol. 291, no. 1-2, pp. 175-185, 2006.

[34] M. M. Ahmed and S. E. Ali, "Protective effect of pomegranate peel ethanol extract against ferric nitrilotriacetate induced renal oxidative damage in rats," Journal of Cell and Molecular Biology, vol. 7-8, no. 1-2, pp. 35-43, 2010.

[35] C. Y. Vargas-Olvera, D. J. Sanchez-Gonzalez, J. D. Solano et al., "Characterization of N-diethylnitrosamine-initiated and ferric nitrilotriacetate-promoted Renal cell carcinoma experimental model and effect of a tamarind seed extract against acute nephrotoxicity and carcinogenesis," Molecular and Cellular Biochemistry, vol. 369, no. 1-2, pp. 105-117, 20122012.

[36] J. D. Hayes and L. I. McLellan, "Glutathione and glutathionedependent enzymes represent a co-ordinately regulated defence against oxidative stress," Free Radical Research, vol. 31, no. 4, pp. 273-300, 1999. 

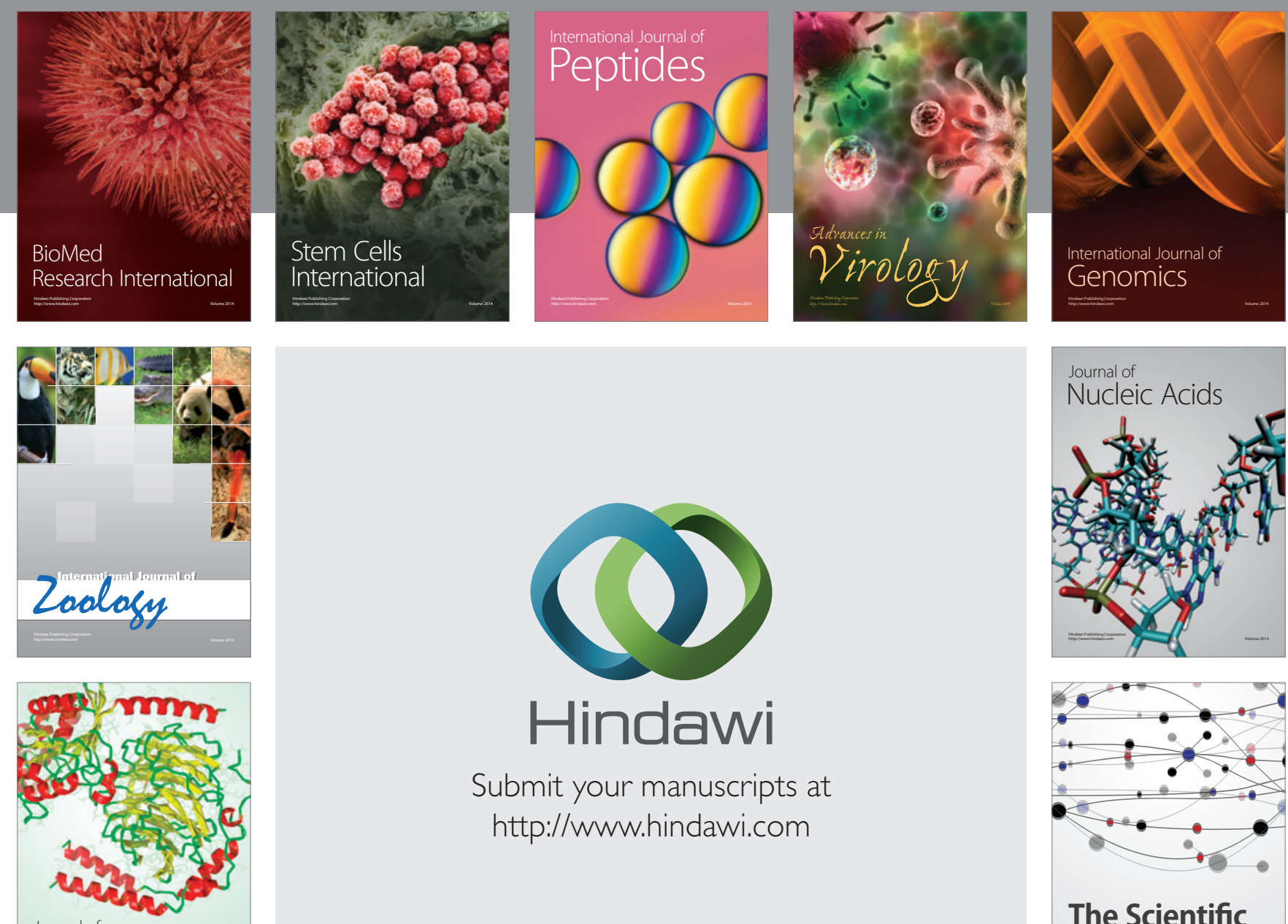

Submit your manuscripts at

http://www.hindawi.com

Journal of
Signal Transduction
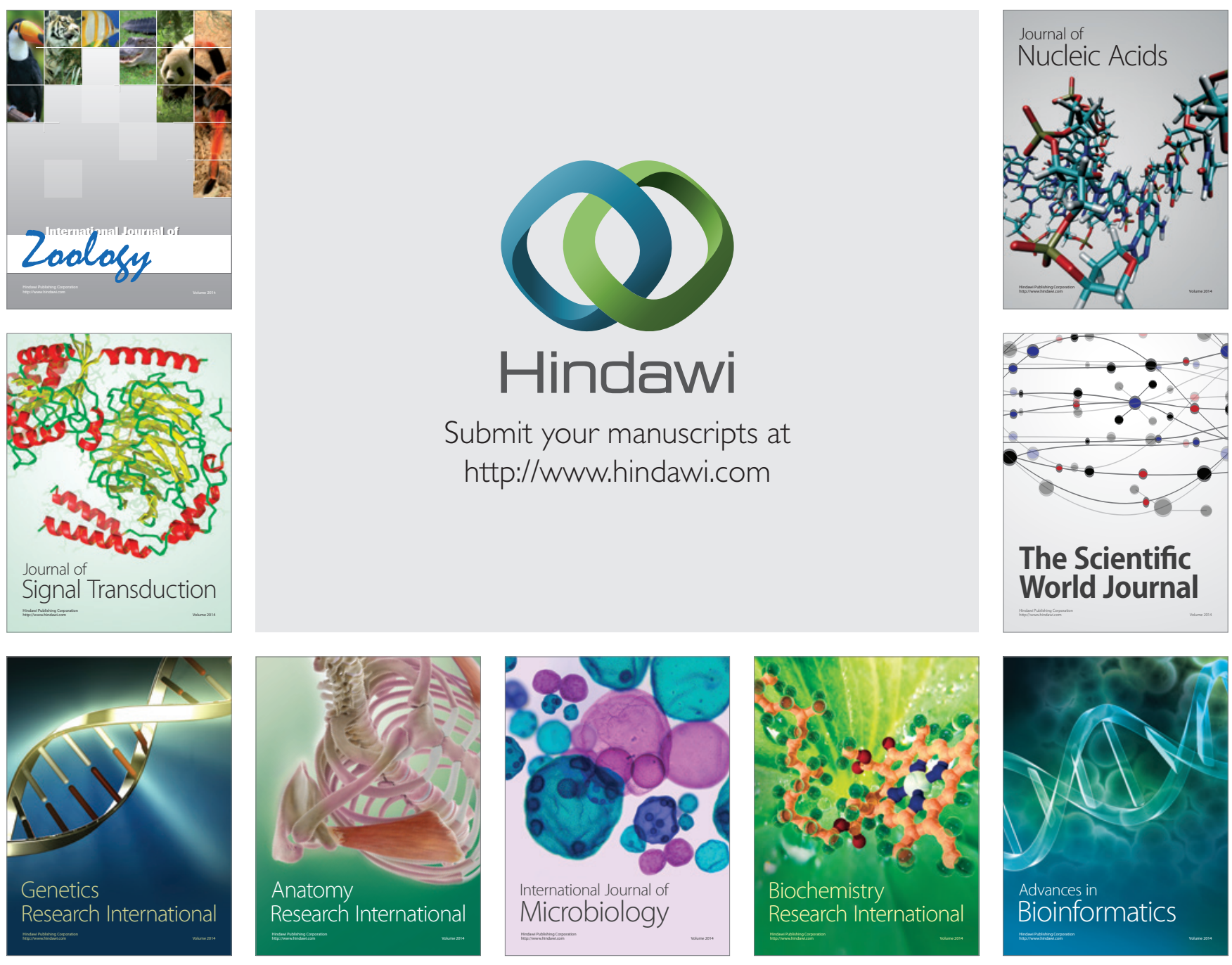

The Scientific World Journal
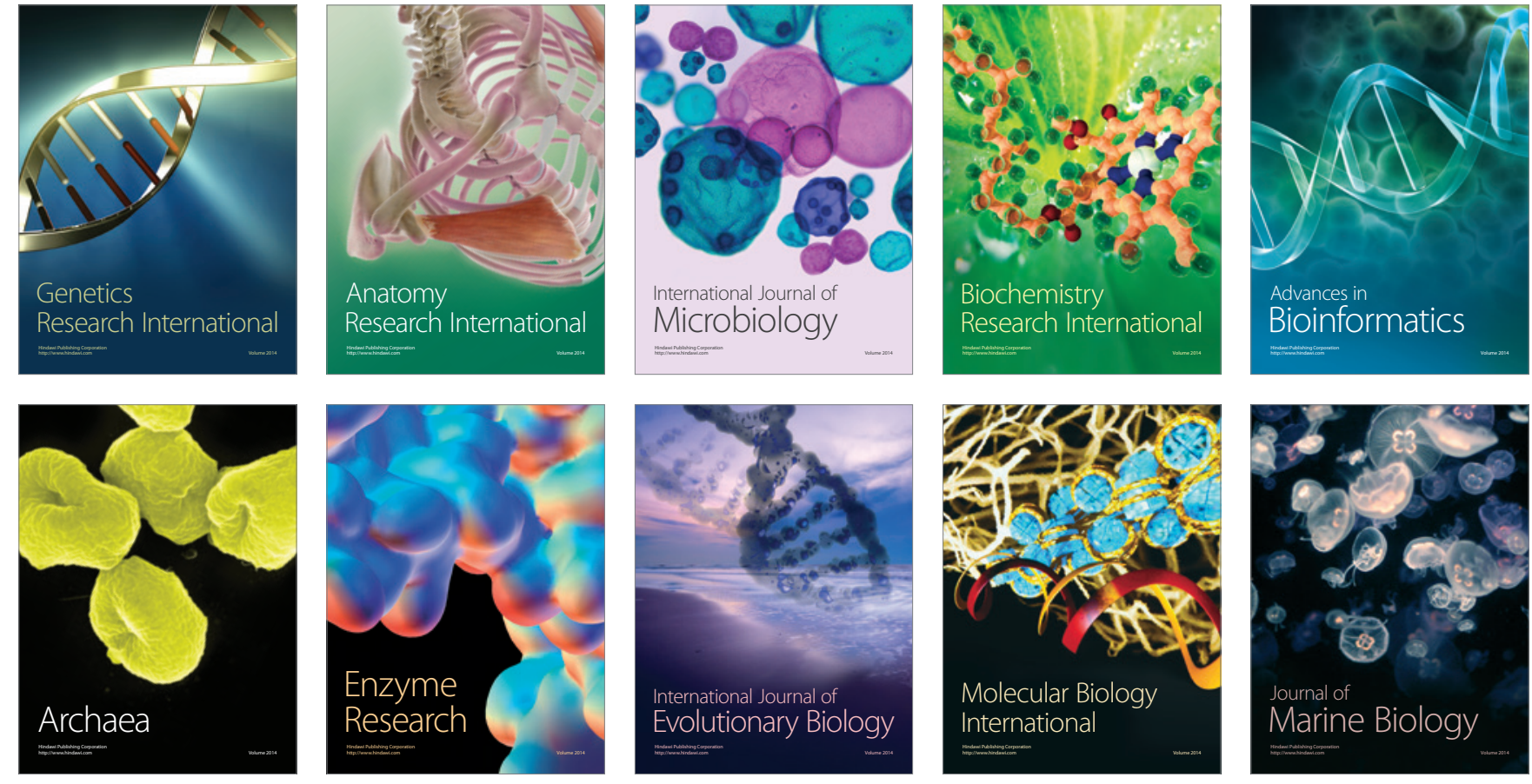